\title{
Syn-sedimentary and early deformation structures as indications for Jurassic pre-orogenic deformation in the SW Bükk Mts.
}

\author{
ÉVA ORAVECZ ${ }^{1,2, \bigotimes}$, SZILVIA KÖVÉR ${ }^{2}$, GÁBOR HÉJA ${ }^{1,3}$ and LÁSZLÓ FODOR ${ }^{1,2}$ \\ ${ }^{1}$ Eötvös Loránd University, Department of Physical and Applied Geology, 1117 Budapest, Pázmány Péter sétány 1/c, Hungary; \\ هorav.eva@gmail.com \\ ${ }^{2}$ MTA-ELTE Geological, Geophysical and Space Sciences Research Groups, 1117 Budapest, Pázmány Péter sétány 1/c, Hungary \\ ${ }^{3}$ Mining and Geological Survey of Hungary, 1145 Budapest, Columbus utca 17, Hungary
}

(Manuscript received November 11, 2019; accepted in revised form June 6, 2020; Associate Editor: Rastislav Vojtko)

\begin{abstract}
Detailed fieldwork was carried out in the SW Bükk Mts. at six locations in order to understand the Jurassic pre-orogenic deformation. All localities expose Middle Jurassic oolitic limestones with grains probably derived from the Adriatic Carbonate Platform and therefore from the Dinaridic passive margin of the Neotethys Ocean. Results of the structural analysis revealed early, soft-sedimentary deformation structures. The observed small-scale normal faults are characterized by rounded, curved shapes without any discrete fault planes (sealed faults) and the displaced beds often thicken towards the faults. These faults were interpreted as syn-sedimentary/syn-diagenetic faults, meaning that the deformation took place in unconsolidated or semi-consolidated sediments. During the early diagenetic silica mobilization, the already-present early faults may have served as conduits of silica-rich fluids, which led to the formation of planar silica injection dykes. Sedimentary slump folds were also identified based on the presence of underlying detachment slip surfaces and the observed thickness changes and onlap surfaces within the folded layers. The significance of these early normal faults and slump folds is that they are the first direct evidence for pre-orogenic deformation in the Bükk Mts. The overall structural data suggest NE-SW or NNE-SSW striking early faults and SE to S verging slump folds in the present-day coordinates. By reconstructing the Cenozoic rotations of the Bükk Mts. this means a roughly NW-SE striking original margin and a south-westward facing paleoslope for the Middle Jurassic. Considering the paleogeographic setting of the Adriatic Platform, this paleoslope direction is possible if the deposition area was located above a deeply submerged tilted normal fault block or alternatively, along the landward side of a larger intraoceanic high. The extensional structures may indicate that the Bükk Mts. were closer to the passive margin than the already ongoing intra-oceanic subduction and related trench, all governed by compression.
\end{abstract}

Keywords: Neotethys, Bükk Mts., pre-orogenic deformation, paleoslope direction, syn-sedimentary deformation, early faults, slump folds.

\section{Introduction}

Reconstruction of former passive margins, their structural geometry and related sedimentary patterns is a difficult task, even in non-metamorphic fold-and-thrust belts (Harfi et al. 2006; Héja et al. 2018), but particularly in orogens that have suffered significant shortening and metamorphism (Beltrando et al. 2014; Mohn et al. 2014; Manatschal \& Nierrengarten 2015). Recognition of pre-orogenic structures may permit the estimation of the strike of the margin and the extensional direction, both of which are crucial input parameters for the reconstructions.

These pre-orogenic structures may include syn-sedimentary or early extensional faults. These general terms are used for faults that formed during or shortly after the sedimentation but certainly before the cementation and consolidation. They may form during either active continental rifting or atectonic slope-related sedimentary deformation, which could be indirectly induced by tectonic processes. In the latter case, early normal faults are often coupled with slumping, and both normal fault strike direction and slump fold vergency generally reflect the geometry of the submarine slope, as well as the underlying former rift geometry. Moreover, pre-orogenic normal faults may form by the flexure of the lower plate during the subduction-related foreland basin evolution (Butler et al. 2006; Carminati et al. 2014).

The problem of recognizing any kind of inherited pre-orogenic structure is even more pronounced in the Bükk Mts. (NE Hungary), which was considerably displaced with respect to the main remnants of the Neotethys Ocean and its margins that are relatively well exposed in the present-day Dinarides (Kovács 1984; Schmid et al. 2008). Consequently, the isolated nature of the Bükk Mts., as well as the low-grade metamorphic overprint and strong folding of the Paleozoic and Mesozoic rocks (Árkai 1983; Csontos 1999) made the recognition of Triassic and Jurassic faults particularly difficult. Both in the Bükk Mts. and in the Dinarides rapid subsidence related to the break-up of the continental crust occurred in the Late Anisian to Early Ladinian, which was followed by the spreading of the Neotethys Ocean during the Late Triassic to Middle 
Jurassic (Gawlick et al. 2012; Sudar et al. 2013). The Triassic sequences of the Bükk Mts. permitted the recognition of tectonically controlled facies differentiation in the Middle Triassic when platforms and intra-platform basins came into existence (Csontos 2000; Velledits 2000, 2006) but the Triassic faults themselves have not been documented yet, neither in outcrops nor on the map-scale.

The present study carried out in the SW Bükk Mts. revealed both sedimentary slumping and early, syn-sedimentary/syndiagenetic normal faulting in the Middle Jurassic Bükkzsérc Limestone (Haas et al. 2011, 2013). In this paper, results of a detailed structural analysis are presented with emphasis on the early deformation structures. These structures are interpreted as indirect indicators for the contemporaneous Middle Jurassic deformation patterns, and for the paleoslope direction, both of which may have implications for reconstructing the paleoposition of the Bükk Mts.

\section{Geological background}

The basement of the Pannonian Basin consists of several tectonic units with different paleogeographic origins and various pre-Miocene deformation histories (Fig. 1, Balla 1983a, 1986a; Kázmér \& Kovács 1985; Csontos et al. 1992; Schmid et al. 2008). The two main tectonic units - the Adria-Apulia related ALCAPA Mega Unit and the Europe related TiszaDacia Mega Unit - are separated by the ENE-WSW trending Mid-Hungarian Shear Zone that lies in the continuation of the Periadriatic Fault (Kázmér \& Kovács 1985; Balla 1988; Csontos \& Nagymarosy 1998; Fodor et al. 1998). Within this shear zone, several smaller tectonic units appear with close relations to the Southern Alps and the NW Dinarides (Haas \& Kovács 2001; Kovács 1982).

The Bükk Mts. with its Dinaric affinity is one of the far-travelled units that were originally positioned on the south-western passive margin of the Neotethys Ocean (Kovács 1984; Schmid et al. 2008). The correlations between the Bükk Mts. and the Inner Dinaric nappe system are based on both lithological correlations of the Paleozoic and Mesozoic formations, as well as on structural correlations (Balogh 1964; Kovács 1982, 1984; Tollmann 1987; Csontos 1988, 2000; Filipović et al. 2003; Schmid et al. 2008).

\section{Stratigraphic settings}

In the Bükk Mts., a rapid subsidence occurred during the Late Anisian to Early Ladinian that is reflected in the development of the sedimentary successions accompanied by syn-rift volcanism (Szentistvánhegy Metaandesite), marking the onset of the Neotethyan rifting (Haas et al. 2011; Szoldán 1990). While Triassic platforms and intraplatform basins are present in the whole Bükk, Jurassic sequences are mostly found in the south-western part of the mountains. Here the Triassic succession terminated with the (Late Ladinian) Norian to Rhaetian cherty limestones of the Felsőtárkány Formation
(Fig. 2, Velledits 2006). The deep marine Jurassic sequences are represented by the Middle Jurassic (Lower Bajocian) Bányahegy Radiolarite and typical slates with fine sandstone intercalations (Lökvölgy Shale and Vaskapu Sandstone, no direct age data available), which were deposited after an Early Jurassic hiatus. These siliciclastic sediments are overlain by the Lower Bathonian to Callovian hemipelagic and eupelagic formations of the Mónosbél Group (Bércziné Makk \& Pelikán 1984; Csontos et al. 1991; Csontos 2000; Pelikán et al. 2005; Haas et al. 2011, 2013).

The Mónosbél Group is the result of repeating debris flows and turbidity currents that transported shallow water materials into the basin (Pelikán et al. 2005; Haas 2007; Haas et al. 2011, 2013). In its lower part, alternating black siltstones and dark grey cherty limestone layers and lenses form the Oldalvölgy Formation. In places, the Oldalvölgy Formation interfingers with the Csipkéstetö Radiolarite. Towards the upper part of the Mónosbél Group, the terrigenous influx became dominant while episodic gravitational mass movements still transported carbonate material from the platform margin and/ or from the upper slope into the basin. Since probably all but one carbonate platform had drowned by this time along the north-western margin of Neotethys, the source of the carbonate grains should have been the Adriatic Carbonate Platform (Haas 2007). Turbidity currents initiating at the platform margin or on the upper slope incorporated the unconsolidated ooids and bioclastic grains while the consolidated limestones were transported as clasts in debris flows or as individual olistoliths. Therefore, oolitic limestones are present in the Mónosbél Group as thin calcite turbidite intercalations within the Oldalvölgy Formation, and as olistoliths or clasts in polymictic olistostrome levels called Laskóvölgy (formerly Mónosbél) Formation (Pelikán 2012).

Moreover, there are a number of relatively large, map-scale occurrences of a well-bedded normal-graded oolitic limestone where it appears in seemingly isolated bodies within the Mónosbél Group. These predominantly redeposited oolitic limestones also contain chert nodules and shale intercalations that were all together assigned to the Bükkzsérc Limestone Formation. Similarly to the calcite turbidite intercalations in the Oldalvölgy Formation, the Bükkzsérc Limestone was also deposited from turbidity currents at a toe-of-slope or in a deeper basinal environment (Haas et al. 2011). However, its thickness and the areal extension of these occurrences made it possible to classify them into a separate mappable formation. The largest known occurrence of the Bükkzsérc Limestone was found in the surroundings of the Bükkzsérc Quarry. Here, according to the latest biostratigraphic studies of Haas et al. (2006) carried out from samples of the Bzs-5 well in quarry yard (Fig. 3, site Bzs01-11), the Bükkzsérc Limestone can be assigned in age to the Early to Late Bajocian (questionably even to the Aalenian). This means that the Bükkzsérc Limestone is older than the surrounding Bathonian to Callovian Oldalvölgy Formation, therefore this occurrence was interpreted as an olistolith (Haas et al. 2011, 2013). However, the age ranges may occasionally overlap and would permit 


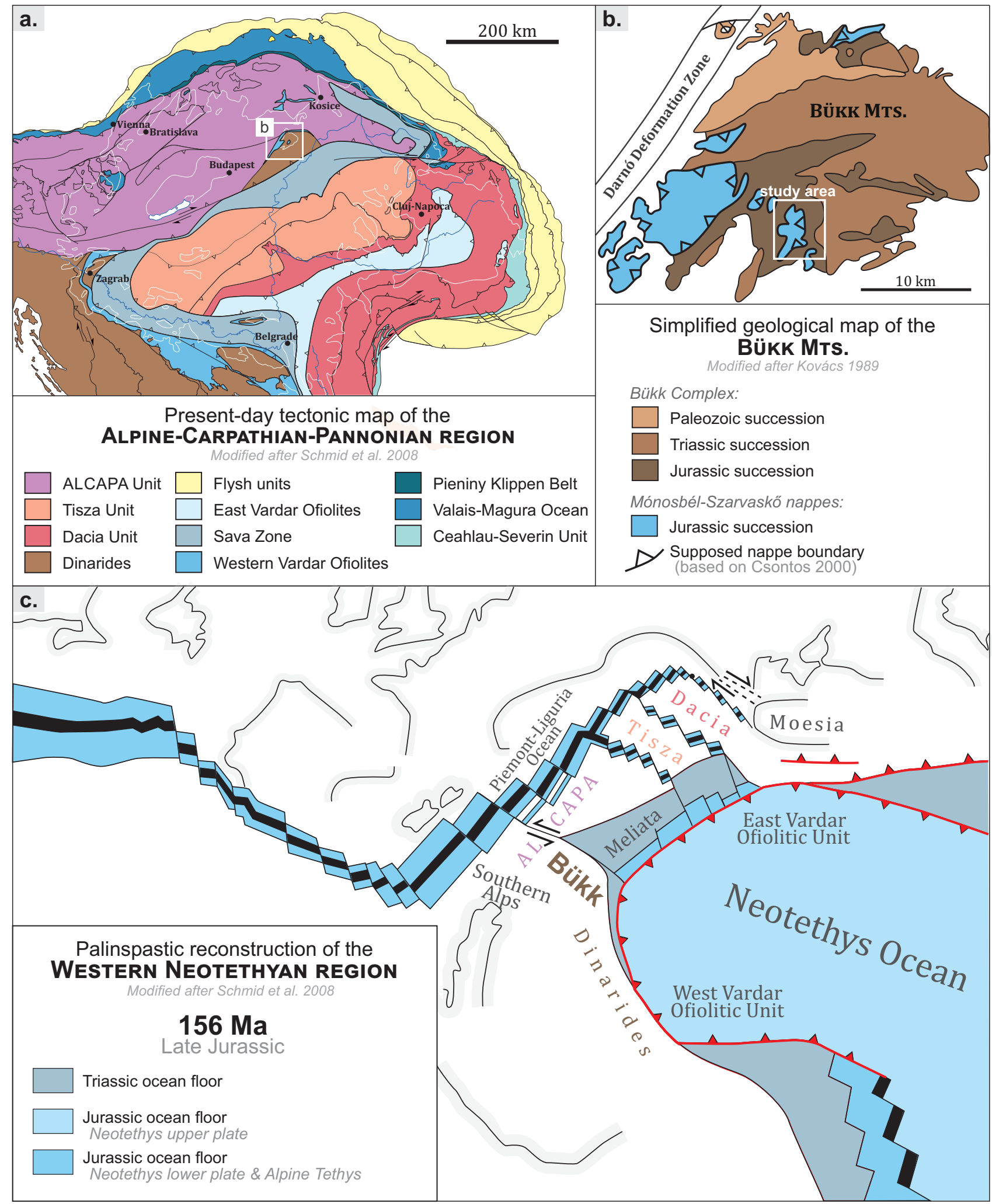

Fig. 1. Present-day position and paleogeographic setting of the study area: a - regional tectonic setting of the Bükk Mts. (modified after Schmid et al. 2008). The Bükk Mts. is a far-travelled structural unit that is correlated with the Inner Dinaridic nappe system; $\mathbf{b}-$ large-scale structure of the Bükk Mts. (modified after Kovács 1989); c — palinspastic reconstruction of the Western Neotethyan realm for the Late Jurassic (modified after Schmid et al. 2008). 
a continuous Bajocian to Bathonian succession as Pelikán \& Dosztály (2000) suggested. In the samples collected at Eregetö (Fig. 3, site Bzs70) Upper Bathonian foraminifers were found (Haas et al. 2011, 2013), suggesting that the oolitic limestones also occur in the upper Middle Jurassic succession either as olistoliths or as interfingering calcarenitic bodies.

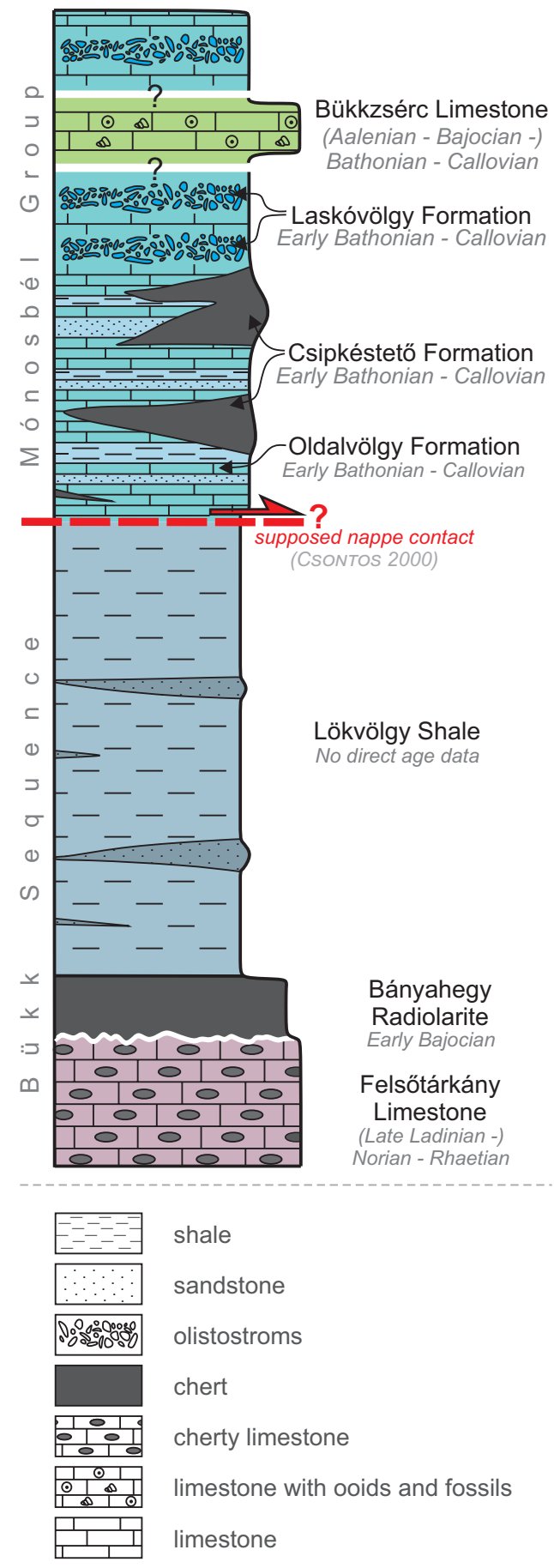

Fig. 2. Schematic geological column of the Upper Triassic to Middle Jurassic succession in the SW Bükk Mts. around the study area (modified after Haas et al. 2011). Either the Bükkzsérc Limestone is an integral part of the sedimentary sequence or it forms separate bodies within the Middle Jurassic succession (e.g., large olistoliths).
Besides the Middle Jurassic oolitic limestones, large Triassic carbonate and basalt olistoliths may also be present in the Mónosbél Group (e.g., Kavicsos Point and Csipkés Hill on Fig. 3a), just as radiolarite and sandstone clasts, metamorphosed and neutral to acidic magmatic rock fragments (Pelikán et al. 2005; Haas et al. 2011; Kövér et al. 2018). The source of these exotic components is still an unsolved problem, although Haas (2007) and Haas et al. $(2011,2013)$ concluded that their presence along with the intensive mass movements may indicate nappe stacking and exhumation of deeper basement units in the vicinity of the Mónosbél depositional area. In this sense, they considered the Mónosbél Group to be the accretionary complex of the Neotethys Ocean that developed in the foreland of the approaching ophiolitic nappes.

\section{Tectonic settings}

Understanding the sedimentological patterns of the Jurassic successions found in the SW Bükk Mts. is crucial in reconstructing the Middle to Late Jurassic tectonic environment, which also includes the change from extensional tectonics related to the rifting and spreading of the Neotethys Ocean to the subduction-related Alpine shortening. Despite all the research in the last 30 years; however, even the large-scale structure of the Bükk Mts. is still the subject of ongoing debates.

Two fundamentally different structural models exist for the Bükk Mts. According to the first model, the Bükk Mts. is made up of a continuous succession from the Carboniferous to the Jurassic (Pelikán et al. 2005). The other and somewhat more accepted model divides the formations into at least four structural units: the Bükk Complex (or Bükk Para-autochtonous Unit) comprises the Paleozoic, Triassic, and lower Middle Jurassic formations and it is overthrust by the MónosbélSzarvaskö Nappes (Balla 1986b; Csontos 2000; Haas \& Kovács 2001). Csontos (1988, 2000) placed the nappe boundary of the Bükk Complex and Mónosbél Nappe between the Middle Jurassic Lökvölgy Formation and the Mónosbél Group (Fig. 2). Unfortunately, this contact zone has no surface outcrops at all. According to this concept, these units were thrust upon each other during the Late Jurassic to Early Cretaceous nappe stacking related to the subduction of the Neotethys Ocean (Csontos 2000; Schmid et al. 2008).

The Mónosbél Unit consists of the resedimented deposits of the Mónosbél Group while the overlying Szarvaskő Nappe contains Middle Jurassic in-situ pillow basalts and gabbros surrounded by quartz-rich sandstones, argillaceous and siliceous pelagic sediments, and olistostromes (Balla 1983b, 1986b; Csontos 2000). Lastly, based on lithological similarities and structural observations the Darnó Unit - exposed further to the west from the Bükk Mts. and found in the highest tectonic position - may be correlated with the Dinaridic subophiolitic mélange (Pamić et al. 2002; Kovács et al. 2010). Contrary to the Dinarides, no sensu-stricto ophiolite nappe is known from the Bükk Mts. 


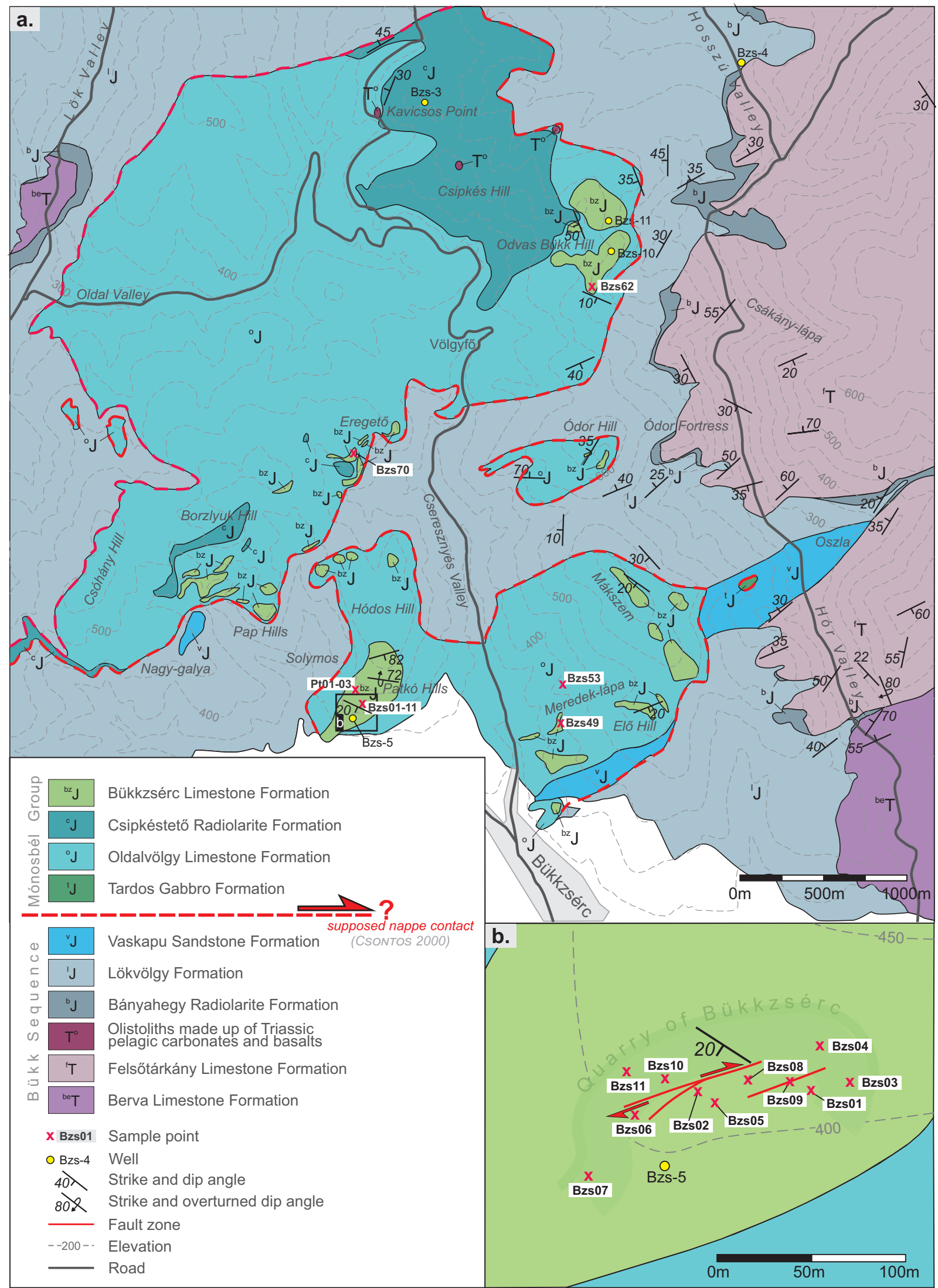

Fig. 3. Maps of the area around Bükkzsérc: a - pre-Cenozoic geological map showing the isolated lens-like occurrences of the Bükkzsérc Limestone (modified after Less et al. 2002 and Haas et al. 2011); b — detailed schematic map of the quarry of Bükkzsérc with the exact location of the observation points. 
The present day structure of the Bükk Mts. is dominated by the structures related to the Late Jurassic (?) to Early Cretaceous shortening (potentially including nappe stacking) on one hand, and to the Middle Miocene extensional deformation of the Pannonian Basin on the other (Csontos 2000; Petrik et al. 2016). Due to the strong structural and low-grade metamorphic overprinting during the Cretaceous; however, very little knowledge is available about the deformations prior to the Late Jurassic. Considering the concepts on the paleoposition of the Dinarides (Schmid et al. 2008), approximately an original NE-SW extension with NE-ward dipping continental slope of the Neotethys margin is expected for the area of the Bükk sequence for the Triassic to Middle Jurassic time span but no direct field evidence has been found or measured so far to confirm it. The Mesozoic facies boundaries and the nappe-stacking related tectonic transport directions integrated with general paleomagnetic data also suggest NE-SW extension.

\section{Materials and methods}

Detailed field work was carried out at two main localities and four other outcrops in the SW Bükk Mts. in order to investigate the deformational features of the Middle Jurassic oolitic limestones (Fig. 3, see Appendix for GPS coordinates). One of the main localities is the Bükkzsérc Quarry (located approximately $1 \mathrm{~km}$ from the village in the NW direction, Bzs01-11), which is the largest continuous exposure of the Bükkzsérc Limestone. The borehole Bzs-5 drilled in the quarry yard reached the bottom of the formation at $56 \mathrm{~m}$, and after an unclear contact, it explored the Lökvölgy Shale below it (Pelikán \& Dosztály 2000). The other main locality is the Patkó Cliffs located uphill above the quarry in the NW direction (Pt01-03), which is part of the same large rock body as the Bükkzsérc Quarry. The other studied sites (Bzs49 and Bzs53 on the Meredek-lápa; Bzs62 at the Völgyfö and Bzs70 on the Eregetö, see Fig. 3) are smaller oolitic limestone outcrops found in the wider surrounding of Bükkzsérc village. These smaller sporadic outcrops serve as control points so that the data from the supposedly olistolith occurrences can be compared.

The field observations were completed by stereographic fault-slip analyses. The fault-slip measurements on the field were followed by fold axis estimations, which were done by using the program package of Angelier (Angelier 1984). Data were separated manually and a tilt-test was carried out using the modul ROTILT on the supposed pre-tilt structures. The pre-tilt nature of the structures was indicated by the geometrical characteristics of the faults and folds (e.g., thickness changes and onlap surfaces within the deformed sedimentary package, the symmetry plane of normal faults being perpendicular to the bedding). In the case of positive tilt-tests, stress field estimations were done on the back-tilted data sets. Finally, the results were rotated by the average Cenozoic rotation values of the Bükk Mts. complied by Márton \& Fodor
(1995) and Márton \& Márton (1996) in order to restore the original Jurassic margin geometry.

\section{Results}

\section{Fold structures}

There is evidence for small-scale folding in the oolitic limestone and chert beds. The folds appear only locally, while the average bedding is around $220 / 20^{\circ}$ in the Bükkzsérc Quarry (Bzs01-11) and at the lower part of the Patkó Cliffs (Pt01-03), 305/40 at site Völgyfö (Bzs62), 330/37 at site Eregető (Bzs70), and 194/18 ${ }^{\circ}$ at site Meredek-lápa (Bzs53) (Fig.3).

The geometries of the observed small-scale folds are very diverse: some folds are cylindrical and appear as monoclines (Fig. 4a) and gentle or open folds (Fig. 4b-d), while others are overturned or recumbent folds with tight to isoclinal hinge zones (Fig. 4a,e). The hinge lines of these overturned folds may be laterally curved (non-cylindrical folds). In extreme cases, the hinges of the folds show quite elongated shape and look similar to sheath folds (Fig. 4f, Alsop \& Holdsworth 2004). The observed fold amplitudes are usually around $10-20 \mathrm{~cm}$ but never exceed $100 \mathrm{~cm}$.

In spite of the different fold geometries, most folds show top-to-S or SE vergency, except for the folds at site Bzs53 where a slight deviation toward the SW was observed, and at site Bzs70 where the vergency of the recumbent folds could not be determined. Almost all the folds are underlain by a detachment surface under which there is no deformation at all (Fig. 4b,c). The folded layers usually show lateral thickness changes and in a number of cases the folds are overlain by undisturbed sedimentary beds onlaping the folds' upper surface (Fig. 4b-d). Moreover, on the folded bedding planes at Bzs02 "soft" striae without any calcite precipitation and with slightly oblique S-SW-vergency were encountered which could be interpreted as stretching lineation that formed in soft-sedimentary state (Ramsey 1960; Ramsey \& Hubert 1987; Ortner 2013).

\section{Sealed faults without discrete planes}

Small-scale normal faults with usually $1-5 \mathrm{~cm}$ or a maximum of $50 \mathrm{~cm}$ offset were discovered in the Bükkzsérc Quarry (Bzs01-11), at the Patkó Cliffs (Pt01-03), and at the sites on Meredek-lápa (Bzs49) and Eregető (Bzs70) (Fig. 3). In cross sections these normal faults flatten out quickly, their planes are generally curved and smooth, particularly at their intersection with the bedding planes (Fig. 5a,b). Furthermore, the faults seemingly have no discrete fault planes or at least they were sealed (cemented) during diagenesis (Fig. 5c,d). The lack of discrete planes is also evident in thin sections where only distorted sedimentary laminae indicate the normal displacement (Fig. 5f). The fault planes always lack any lineation and are often sealed by the subsequent undeformed layers 
(Fig. 5a). Occasionally thickening toward the faults and dilatational jogs filled with the shale of the subsequent sealing beds was also observed (Fig. 5d,e). Although small changes in their strike directions always occur, the general strike of these normal faults is between NE-SW and E-W.

\section{Silica dykes}

Dykes filled with silica were discovered only in the Bükkzsérc Quarry at the site Bzs02 (Fig. 6). The geometry of these silica dykes imply that they are related to structural elements:
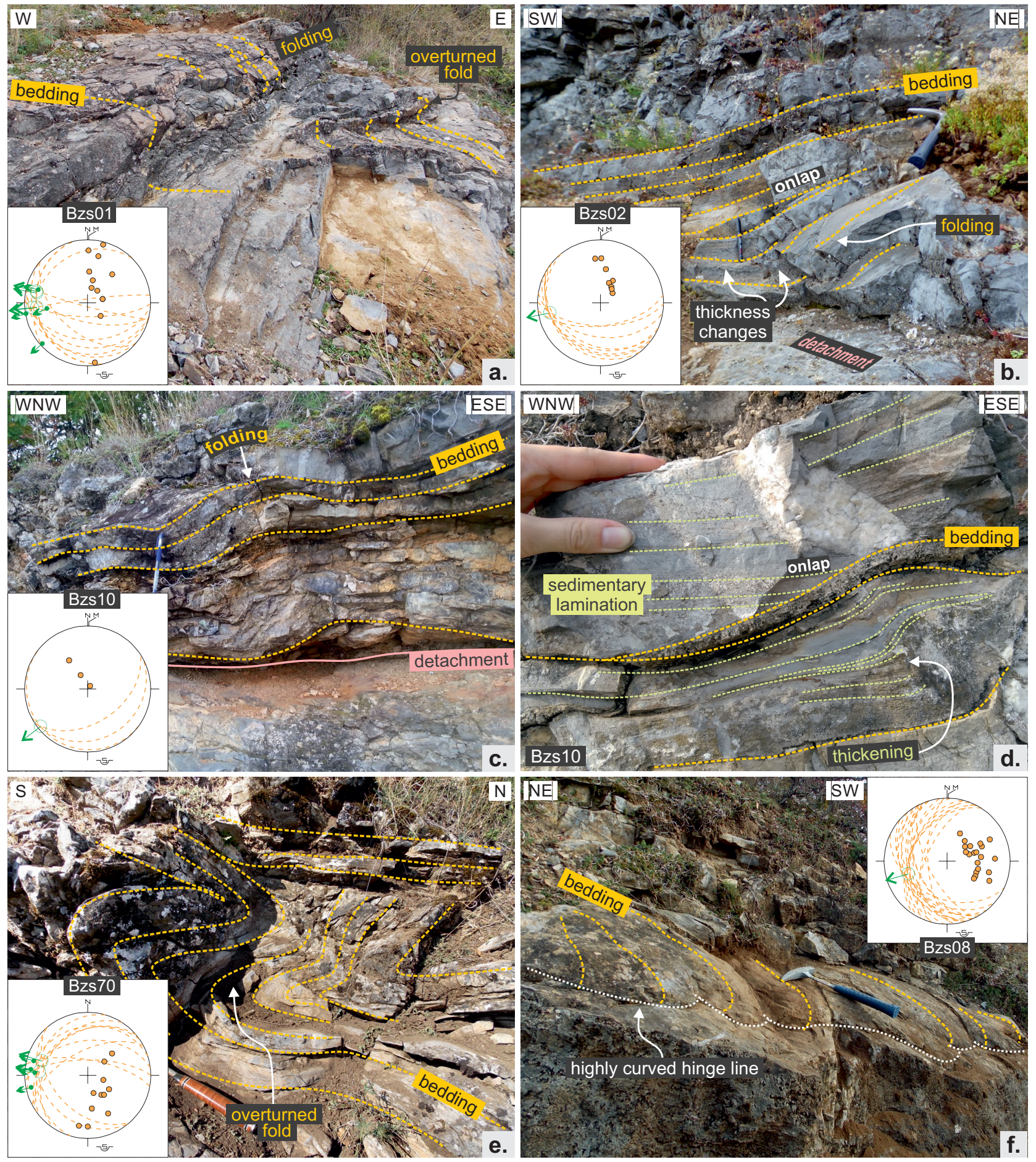

Fig. 4. Field photos of the small-scale folds observed in the quarry of Bükkzsérc and on the Eregető (see stereoplot legend in Fig. 7): $\mathbf{a}$ - monoclines and an overturned fold in deformed chert layers; $\mathbf{b}-\mathbf{d}$ - gentle cylindrical folds that formed above detachments and have strata onlapping on the folds' surfaces; $\mathbf{e}$ - intensively folded limestone beds with sub-horizontal axial plane; $\mathbf{f}$ - non-cylindrical folds with curved hinge lines. Geometrically these folds are very similar to pillow basalts. 

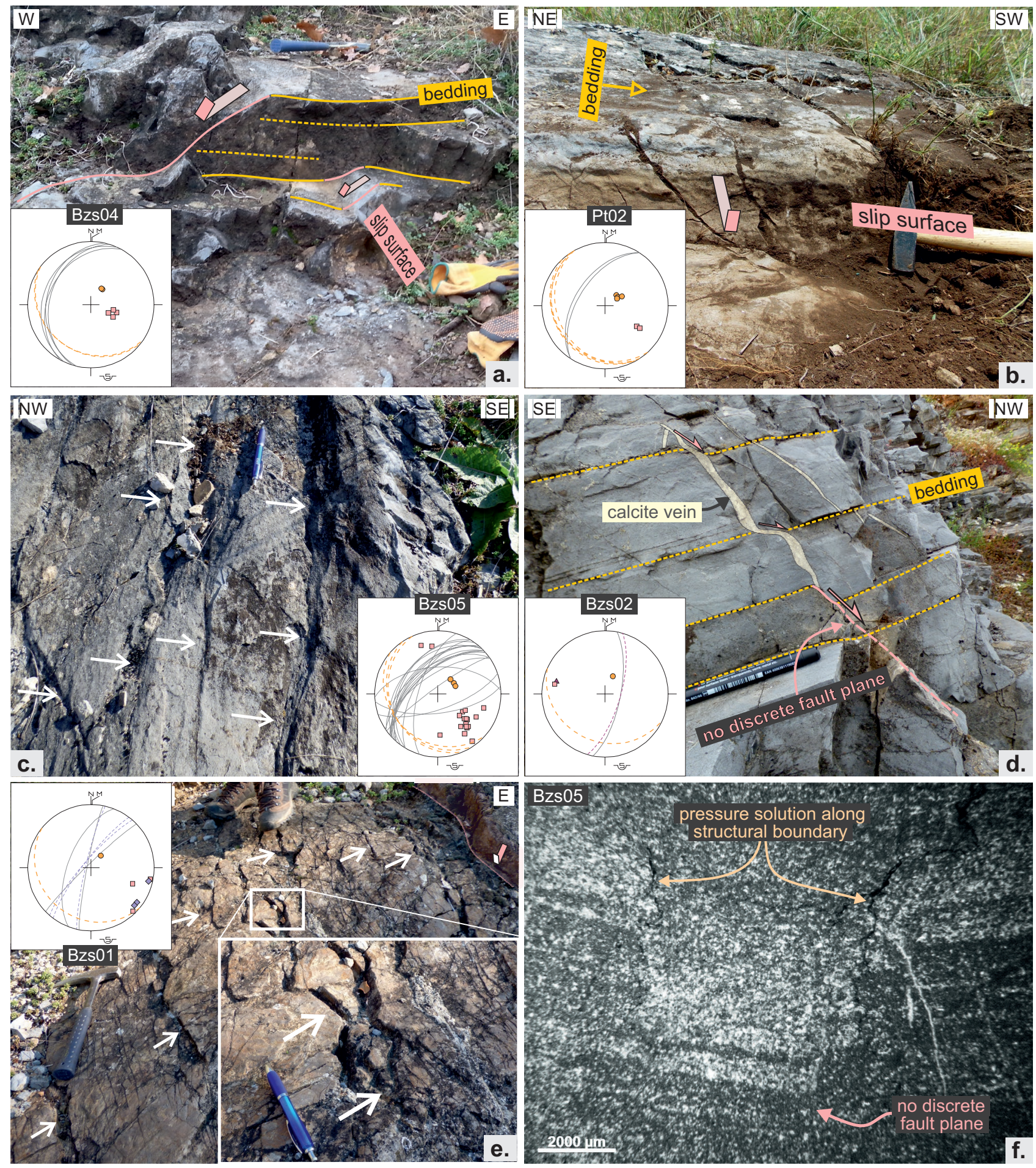

Fig. 5. Field photos and thin section view of the observed normal faults and slip surfaces (see stereoplot legend in Fig.7): a, b - field photos of normal faults, which are shallower than the ideal $60^{\circ}$ and flatten into the bedding planes. The fault planes always lack any striae and are often sealed by the subsequent beds; $\mathbf{c}, \mathbf{d}$ - field photos of normal faults without discrete fault planes. In general, they have only a few centimetres offset and are sealed by the subsequent undeformed beds; $\mathbf{e}$ - field photo of several small-scale normal faults that showed more discrete features but the fault crevices were filled with the shale of the subsequent covering bed; $\mathbf{f}$ - optical microscope view of a normal fault conjugate pair in thin section. Due to the lack of discrete fault planes, the presence of the faults is evident only by the offset of bedding. 
they obviously appear along planar or gently undulating surfaces that can be traced for several metres. At the lower or upper terminations of the dykes, irregular chert nodules are usually present, and there is a gradual transition between the host limestone and the chert, which can be observed both on the field and in thin sections (Fig. 6b). The strike of these elements varies between ENE-WSW and SE-NW.

\section{Discrete fractures and calcite veins}

Both in the Bükkzsérc Quarry and at the Patkó Cliffs numerous brittle structures, which include discrete planar faults with kinematic indicators (calcite fiber lineations and slickolitic striations), joints and calcite veins could be observed. They are mainly concentrated around two main ENE-WSW striking restraining dextral strike-slip faults (Fig. 3b). Reactivation of faults and overprinting generation of lineation are common. As these brittle structural elements were already observed and classified by Németh (2007) they will not be discussed in detail here.

\section{Discussions}

\section{Interpretation of the observed structures}

\section{Fold structures related to soft-sedimentary slumping}

Most observations on geometry of the small-scale fold structures indicate soft-sedimentary slumping (Lewis 1971; Alsop \& Marco 2011; Peel 2014). These observations include the detachments underlying the folded strata (Fig. 4c,d), the lateral thickness changes within the deformed layers (Fig. 4c), the onlapping of the thinning layers on the folds' upper surface and the undeformed beds sealing the folds (Fig. 4c,e). Moreover, the geometrical variability of the folds involves a spectrum from (1) slight cylindrical monoclines to recumbent folds and (2) non-cylindrical sheath folds with laterally curved hinge lines. This variability is also typical for slump folds (Alsop \& Marco 2011). In the case of these smallscale slump folds, the deformation must have developed in semi-consolidated sediments via granular flow (i.e. combination of grain boundary sliding and grain rotation), which is a viable deformation mechanism both in non-consolidated plastic sediments and poorly cohesive rocks in brittle field as well (Owen 1987; Owen et al. 2011).

\section{Syn-sedimentary normal faults and related dykes}

According to our interpretation, the small-scale normal faults without well-defined (discrete) fault planes or with cemented narrow zones are early (syn-sedimentary or syndiagenetic) tectonic faults, which formed prior to complete consolidation (Fig. 5). Opposite to post-diagenetic deformation that results in discrete fault planes, the deformation is distributed in a wider shear zone in soft sediments. In addition,
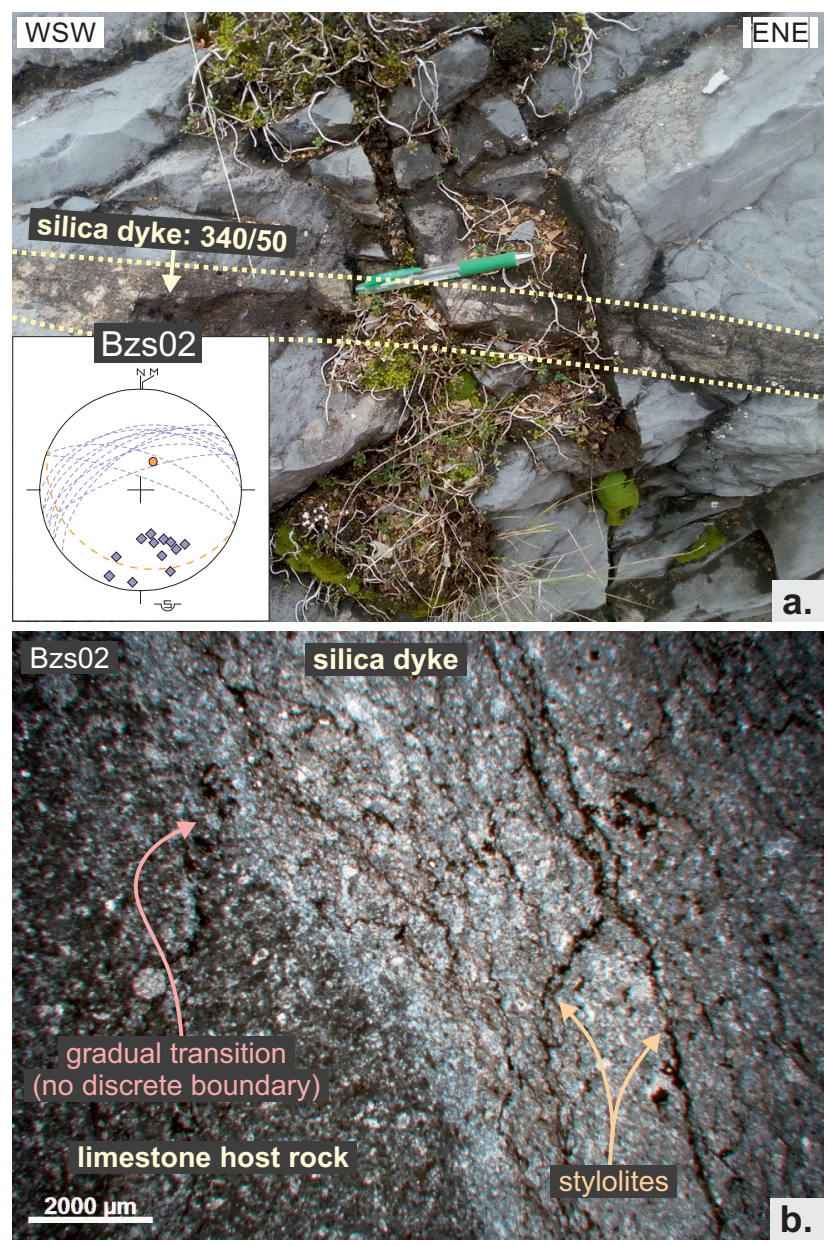

Fig. 6. Field photo (a) and optical microscope view (b) of a silica dyke. Based on their planar features these silica dykes probably formed along pre-existing faults. The interface between the silica and the host limestone is not a definite boundary but shows a gradual transition (see stereoplot legend in Fig.7).

the normal faults are flatter than the ideal $60^{\circ}$ and they often have listric geometry (Prestholm \& Walderhaug 2000). This can be connected to the vertical shortening due to compaction. On the other hand, the later diagenetic processes (e.g., by dewatering or cementation) can overprint or completely erase the previous small planar structures. The lack of any striations on the fault planes also indicates soft-sedimentary deformation. Thus, the "healed" or "closed" faults without discrete planes and with relatively small displacement are the results of the syn-sedimentary or syn-diagenetic deformation of the studied rocks. A few examples of hanging wall thickening and the sediment-filled dykes also point to syn-sedimentary deformations. In several cases the structures are overprinted by (sub-horizontal) stylolites (Figs. 5f, 6b) showing that they were formed as the earliest deformation structures.

In addition to the faults, the gradual transition from silica to limestone proves that the silica dykes are injection dykes formed in an early stage of the diagenesis, immediately after the silica became mobilized (Fig. 6). The source of silica was 
most probably biogenetic, meaning the tests of radiolarians and sponge spicules went through an early diagenetic transformation. Injection dykes are often related to early faults because they could serve as already present weakness zones (Tanner 1998; Giménez-Montsant et al. 1999; Ribeiro \& Terrinha 2007). This is also supported by the planar geometry of the silica dykes, they are therefore indications for an early-phase deformation as well.

\section{Estimations for the Middle Jurassic paleostress field and paleoslope direction}

As syn-sedimentary to early tectonic deformation structures have implications for the earliest deformation history of the rocks, the paleostress field for the Bajocian to Bathonian may be estimated based on the measured data, and folds and slide surfaces related to sedimentary slumping may have indications for the paleoslope direction. The significance of this is that these early deformation structures in the oolitic Bükkzsérc-type limestone are the only direct structural evidence so far for the pre-orogenic deformation of the area of the Bükk Mts.

The original idea behind paleoslope estimations was that slump fold axes reflect the strike of the paleoslope as being perpendicular to the main slope gradient (Jones 1939; Woodcock 1979). However, a number of studies carried out in the last decades suggested that estimations based on measured fold axes are not as straightforward as previously thought. The new approaches are based on the fact that slump folds may manifest in various geometries starting from simple cylindrical and monocline folds (like Fig. 4a-e) to extremely elongated non-cylindrical folds and sheath folds (like Fig. 4f). In case of non-cylindrical folds, due to the lateral bending of the hinge line - depending on the observed part of the fold structure - the axis may be oriented even parallel to the slope strike (Hansen 1971; Alsop \& Holdsworth 2002; Strachen \& Alsop 2006).

Considering the geometrical factor, we estimated fold axes separately for every slump fold. The results of these estimations complemented with the fold vergencies in the Bükkzsérc Quarry and at the Patkó Cliffs suggest an approximately SE or SSE paleoslope direction in the present-day coordinate system (Fig. 7). A few sites show fold vergency to the SW (Bzs53 and Bzs70 in Fig. 7); similar directional variability is present in many ancient slide complexes (Alsop \& Marco 2011; Weinberger et al. 2017). The main slump direction correlates well with the NE-SW or NNE-SSW striking early normal faults and silica dykes if one assumed their parallelism with the strike of the slope. The sporadic data from the other oolitic limestone occurrences consistently show the same syn-sedimentary/syn-diagenetic extensional and paleoslope directions, suggesting that the observed oolitic limestone bodies are either normal parts of the succession (not olistoliths), or olistoliths of these large sizes did not rotate further around their vertical axis during gravitational downsliding.

\section{Implications for the Middle Jurassic margin geometry}

To reconstruct the Middle Jurassic paleodirections, knowledge about paleomagnetic data would be necessary directly from the studied outcrops, as well as from the surrounding formations, especially if at least some part of the Bükkzsérc Limestone is preserved in olistoliths. We tried to determine the original paleodeclinations from these sites but failed to do so due to remagnetization caused by metamorphic overprint. In the absence of such specific paleomagnetic data, the general $80^{\circ}$ counter-clockwise rotation attributed for the Cenozoic deformation of the whole Bükk Mts. was used to reconstruct the original paleostress field and the estimated paleoslope direction (Márton \& Fodor 1995; Márton \& Márton 1996). This may be an acceptable approximation considering that the measured sedimentary and early deformation structures show consistent directions at every individual locality.

The back-rotated data suggest a roughly NW-SE striking margin and SW-directed paleoslope for the Middle Jurassic (Fig. 8a,b). This inferred strike directions of the margin is in agreement with the previous passive margin reconstructions that were mainly based on facies distributions (Gawlick et al. 1999; Csontos 2000; Schmid et al. 2008) and paleomagnetic data from the ophiolites projected for the direction of the margins (Maffione \& van Hinsbergen 2018). The coincidence may lead to a suggestion that the extensional deformation is connected to the evolution of the Adriatic margin.

The initiation of the subduction of the Neotethys Ocean (Maffione \& van Hinsbergen 2018; Schmid et al. 2008) happened at approximately the same time as the deposition of the Bükkzsérc Limestone and the rest of the Mónosbél Group. This geodynamic framework led several authors to suggest an accretionary origin of all the mid-Jurassic successions (Dosztály et al. 1998; Csontos 2000; Haas 2007; Haas et al. 2011, 2013). We will not discuss this issue in detail but a recent review of clasts may offer an alternative explanation (Fodor et al. 2018). The overwhelming majority of the clasts and redeposited grains were either derived from the Adriatic margin (the platform carbonates of this study, the Triassic volcanic rocks in Kövér et al. 2018) or their origin is not unequivocal (e.g., radiolarites, sandstones). No ultrabasic rocks or gabbros are known in the Mónosbél Group; therefore, we suggest that its depositional area was not in the imminent vicinity of the intraoceanic subduction zone of the Neotethys Ocean (Fodor et al. 2018).

Intensive mass movements and olistostromes occur in passive margin environments as well (Naylor 1981) and the exotic components of the polymictic olistostromes could have come from extensionally unroofed units of the Adriatic margin. Reactivation of syn-rift normal faults could happen due to the initial bending of the downgoing Adriatic lithosphere; in this scenario, local extension is directly related to subduction. On the other hand, in the Slovenian Basin a very similar resedimented succession was encountered in the Middle to Upper Jurassic (Rožič \& Popit 2006; Rožič et al. 2018). The sequence was connected either to renewed normal 


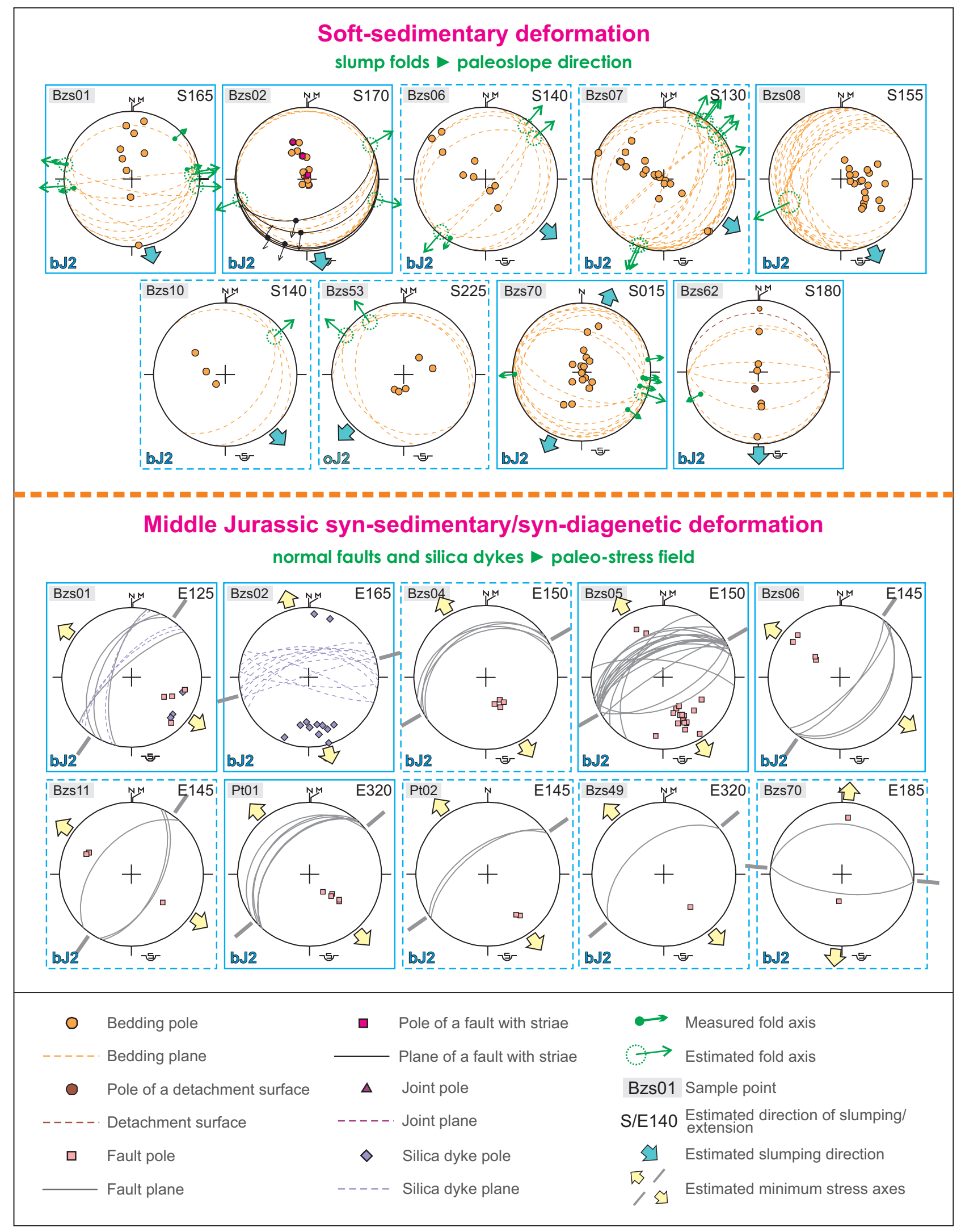

Fig. 7. Stereoplot examples for soft-sedimentary slump folds and syn-sedimentary/syn-diagenetic normal faults and silica dykes. All data are back-tilted by the local average dip. Most slump fold vergency and the stretching lineations at the site Bzs02 indicate S- or SE-ward paleoslope direction. This correlates well with the NW-SE or NNW-SSE extensional direction inferred from the early normal faults and the silica dykes. 


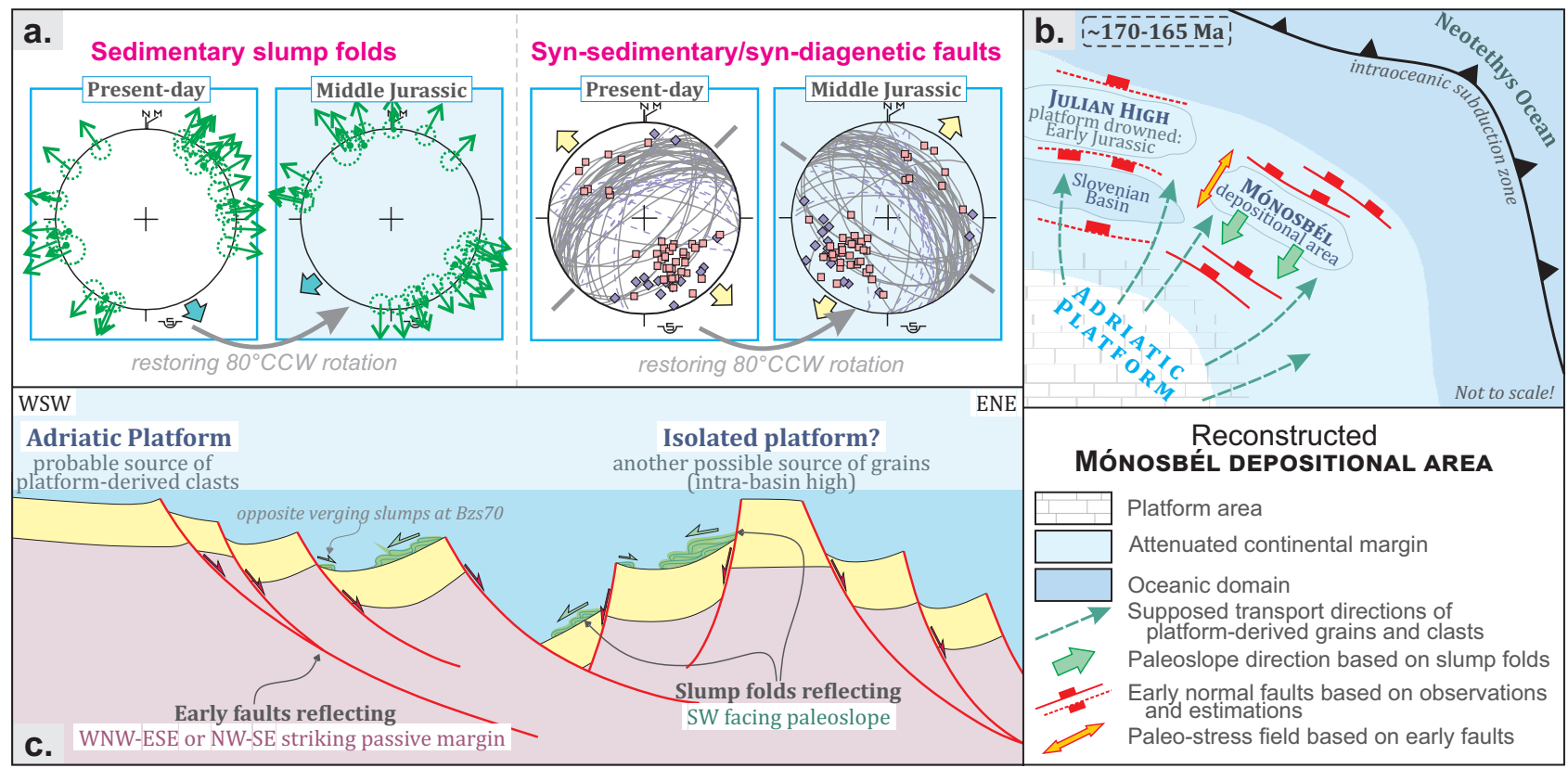

Fig. 8. Reconstructions of the Mónosbél deposition area for the Middle Jurassic: a — summarized stereoplots for the sedimentary slump folds and early faults. The stereoplots are rotated by $80^{\circ}$ in clockwise direction to restore the general Cenozoic $80^{\circ}$ counter-clockwise rotation of the Bükk Mts. (Márton \& Fodor 1995; Márton \& Márton 1996) in order to restore the original Middle Jurassic directions (see stereoplot legend in Fig. 7); b - reconstructed Middle Jurassic paleogeographic map of the Mónosbél depositional area based on the estimated WNW-ESE and NW-SE striking early normal faults and south-westward facing paleoslope direction. The geometry of the intraoceanic subduction zone was drawn according to the results of Maffione \& van Hinsbergen (2018); c - schematic cross-section through an idealized continental margin, presenting the possible deposition areas of the oolitic Bükkzsérc-type limestones within the passive margin. The source of the platform-derived grains could be either the Adriatic Carbonate Platform or a yet-unknown isolated platform within the basin.

faulting of the Triassic rifted margin or to the formation of new Jurassic faults (Fig. 8b). The reason for this normal faulting is somewhat speculative but could be connected to the coeval opening of the Alpine Tethys (Piemont-Ligurian Ocean) west from the study area (Schmid et al. 2008). These data from the surroundings of the depositional area of the Bükk sequences may suggest that the observed extensional structures could be connected to renewed extension on the northern Adriatic margin, and this deformation was spatially distinct from the ongoing subduction.

On the Adriatic margin the SW-directed paleoslope seems to be controversial at first glance: the area of the Bükk Mts., along with the Dinaridic domain, was located on the southwestern margin of the Neotethys Ocean, therefore an opposite NE-directed continental slope direction was expected (Fig. 8c). Furthermore, the Bükk Unit along with the Julian Alps was tectonically separated from the Adriatic Platform by the Slovenian Basin since the Ladinian. This currently E-W directed basin, located on the attenuated continental margin preserved its deeper marine character throughout the Mesozoic up to the Maastrichtian while the Bükk and Julian Alps remained somewhat uplifted areas in the Triassic and subsided in the Jurassic (Buser 1989; Haas 2007; Haas et al. 2011, 2013; Goričan et al. 2013).

Considering all this, if the platform-derived carbonate grains and clasts truly came from the Dinaridic Platform, the turbidity currents had to first cross the Slovenian Basin and then "climb" up to the depositional area. As turbidity currents are able to flow upslope and cross intra-oceanic highs (Damuth \& Embley 1979; Dolan et al. 1989; Tőkés \& Sztanó 2015), this could be a viable scenario. For the south-westward facing slump folds to form, the deposition of the Bükkzsérc Limestone and the Mónosbél Group had to happen on the top of a submerged tilted normal fault block tilted backward toward the platform. Alternatively, deposition on the landward side of a larger intra-oceanic high (for example, an extensional allochthon block, Péron-Pinvidič et al. 2013) is a viable hypothesis (Fig. 8c). In the latter case, however, it cannot be completely excluded that a yet-unknown isolated platform might have survived locally and still have existed during the Middle Jurassic somewhere NE of the depositional area that could have provided bioclasts for gravity mass flows.

\section{Conclusions}

As a result of our field work in the SW Bükk Mts., early syn-sedimentary or syn-diagenetic normal faults, silica dykes, and sedimentary slump folds were identified and used for reconstructing the Middle Jurassic margin geometry. These early structures are the first direct structural evidence for the pre-orogenic deformation in the Bükk Mts.

The observed early faults presented NE-SW or NNE-SSW strike directions and the slump faults had an average SE to $\mathrm{S}$ 
vergency in the present-day coordinates. After reconstructing the Cenozoic rotations, our estimations suggest a roughly NW-SE striking Middle Jurassic margin with a south-westward facing paleoslope for the depositional area of the Middle Jurassic oolitic calci-turbidites and resedimented platform material or upper slope derived carbonate clasts and olistoliths. As the source of the carbonate grains and clasts should be the Adriatic Platform located to the SW, the deposition area might have been located above a deeply submerged tilted normal fault block or alternatively, along the landward side of an intra-oceanic high. Based on the structural data, however, the local existence of a still unknown intra-basin platform NE of the depositional area cannot be completely excluded. In all models, the extensional deformation is in contrast with the coeval onset of intra-oceanic subduction. However, this is not a real controversy but a spatial difference of deformational style; renewed extension close to the Adriatic margin and contraction in a still distally located subduction zone.

Acknowledgements: The research was supported by the research fund NKFIH OTKA 113013 and the ÚNKP-16-1 New National Excellence Program of the Ministry of Human Capacities. The field assistance of Sándor Holló from the Bükk National Park (Eger) is greatly appreciated. The constructive comments of the reviewers (J. Haas, Gy. Less and J. Hók) and the editorial help of R. Vojtko are acknowledged here.

\section{References}

Alsop G.I. \& Holdsworth R.E. 2002: The geometry and kinematics of flow perturbation folds. Tectonophysics 350, 2, 99-125. https://doi.org/10.1016/S0040-1951(02)00084-7

Alsop G.I. \& Holdsworth R.E. 2004: The geometry and topology of natural sheath folds: a new tool for structural analysis. J. Struct. Geol. 26, 1561-1589. https://doi.org/10.1016/j.jsg.2004.01.009

Alsop G.I. \& Marco S. 2011: Soft-sediment deformation within seismogenic slumps of the Dead Sea Basin. J. Struct. Geol. 33, 433-457. https://doi.org/10.1016/j.jsg.2011.02.003

Angelier J. 1984: Tectonic analysis of fault slip data sets. J. Geophys. Res. 89, B7, 5835-5848.

Árkai P. 1983: Very low- and low-grade alpine regional metamorphism of the Paleozoic and Mesozoic formations of the Bükkium, NE-Hungary. Acta Geologica Hungarica 26, 1-2, 83-101.

Balla Z. 1983a: Development of the Pannonian basin basement through the Cretaceous-Cenozoic collision: A new synthesis. Tectonophysics 88, 1-2, 61-102.

Balla Z. 1983b: A Szarvaskői-szinform rétegsora és tektonikája. Annals of the Eötvös Loránd Geophysical Institute of Hungary from 1982, 42-65 (in Hungarian).

Balla Z. 1986a: Palaeotectonic reconstruction of the central AlpineMediterranean belt for the Neogene. Tectonophysics 127, 3, 213-243.

Balla Z. 1986b: Mesozoic tectonics of the Bükk Mountains (North Hungary) and relations to the West Carpathians and Dinarides. Általános Földtani Szemle 22, 13-54 (in Hungarian with English abstract).

Balla Z. 1988: Clockwise paleomagnetic rotations in the Alps in the light of the structural pattern of the Transdanubian Range (Hungary). Tectonophysics 145, 3-4, 277-292.
Balogh K. 1964: Geology of the Bükk Mts.. Annals of the Geological Institute of Hungary 48, 2, 558-713 (in Hungarian).

Beltrando M., Manatschal G., Mohn G., Dal Piaz G.V., Brovarone A.V. \& Masini E. 2014: Recognizing remnants of magma-poor rifted margins in high-pressure orogenic belts: The Alpine case study. Earth-Sci. Rev. 131, 88-115. https://doi.org/10.1016/ j.earscirev.2014.01.001

Bércziné Makk A. \& Pelikán P. 1984: Jurassic formations from the Bükk Mountains. Annals of the Geological Institute of Hungary from 1982, 137-166 (in Hungarian with English abstract).

Buser S. 1989: Development of the Dinaric and Julian carbonate platforms and the intermediate Slovenian Basin (NW Jugoslavia). In: Carulli G.B., Cucchi F. \& Radrizzani C.P. (Eds.): Evolution of the karstic carbonate platform: relation with other periadriatic carbonate platforms. Memorie della Società Geologica Italiana 40, 313-320.

Butler R.W.H., Tavarnelli E. \& Grasso M. 2006: Structural inheritance in mountain belts: An Alpine-Appenine perspective. J. Struct. Geol. 28, 1893-1908. https://doi.org/10.1016/j.jsg.2006.09.006

Carminati E., Fabbi S. \& Santantonio M. 2014: Slab bending, syn-subduction normal faulting, and out-of-sequence thrusting in the Central Appenines. Tectonics 33, 4, 530-551. https://doi. org/10.1002/2013TC003386

Csontos L. 1988: Étude géologique d'une portion des Carpathes Internes, le massif du Bükk (Nord-est de la Hongrie), stratigraphique, structures, métamorphisme et géodinamique. PhD thesis, University de Lille Flandres-Artois.

Csontos L. 1999: Structural outline of the Bükk Mts (N Hungary). Földtani Közlöny 129, 4, 611-651 (in Hungarian with English abstract).

Csontos L. 2000: Stratigraphic reevaluation of the Bükk Mts (N. Hungary). Földtani Közlöny 130, 1, 95-131 (in Hungarian with English abstract).

Csontos L. \& Nagymarosy A. 1998: The Mid-Hungarian Line: a zone of repeated tectonic inversions. Tectonophysics 297, 51-71. https://doi.org/10.1016/S0040-1951(98)00163-2

Csontos L., Bércziné Makk A. \& Thiebault F. 1991: New foraminifera fossils from the S-Bükk Mts. Annals of the Geological Institute of Hungary from 1989, 383-409 (in Hungarian).

Csontos L. Nagymarosy A., Horváth F. \& Kováč M. 1992: Tertiary evolution of the Intra-Carpathian area: a model. Tectonophysics 208, 221-241. https://doi.org/10.1016/0040-1951(92)90346-8

Damuth J.E. \& Embley R.W. 1979: Upslope flow of turbidity currents on the northwest flank of the Ceará Rise: western Equatorial Atlantic. Sedimentology 26, 825-834.

Dolan J., Beck C. \& Ogawa Y. 1989: Upslope deposition of extremely distal turbidites: An example from the Tiburon Rise, west-central Atlantic. Geology 17, 990-994.

Dosztály L., Gulácsi Z. \& Kovács S. 1998: Stratigraphy of the Jurassic formations in North Hungary. In: Bércziné I. \& Jámbor Á. (Eds): Magyarország geológiai képződményeinek rétegtana. Mol Rt. - Magyar Állami Földtani Intézet, 309-318 (in Hungarian).

Filipović I., Jovanović D., Sudar M., Pelikán P., Kovács S., Less Gy. \& Hips K. 2003: Comparison of the Variscan-Early Alpine evolution of the Jadar block (NW Serbia) and Bükkium (NE Hungary) terranes; some paleogeographic implications. Slovak Geological Magazine 9, 23-40.

Fodor L., Jelen B., Márton E., Skaberne D., Čar J. \& Vrabec M. 1998: Miocene-Pliocene tectonic evolution of the Slovenian Periadriatic fault: Implications for Alpine-Carpathian extrusion models. Tectonics 17, 5, 690-709.

Fodor L., Kövér Sz., Kiss G.B., Derić N., Fialowski M., Götz A., Gulácsi Z., Haas J., Kovács Z., Oravecz É., Reiser M., Scherman B. \& Schuster R. 2018: Previous concepts and new data on the structural and magmatic evolution of the Bükk Mts, NE Hungary: 
first step toward the reconsideration of geodynamic models. In: $16^{\text {th }}$ Meeting of the Central European Tectonic Studies Group (CETEG), Rytro, Poland, Abstract book, 155-156.

Gawlick H-J., Frisch W., Vecsei A., Steiger T. \& Böhm F. 1999: The change from rifting to thrusting in the Northern Calcareous Alps as recorded in Jurassic sediments. Geol. Rundsch. 87, 644-657. https://doi.org/10.1007/s005310050237

Gawlick H-J., Goričan Š., Missoni S. \& Lein R. 2012: Late Anisian platform drowning and radiolarite deposition as a consequence of the opening of the Neotethys ocean (High Karst nappe, Montenegro). Bulletin de la Société Géologique de France 183, 4, 349-358. https://doi.org/10.2113/gssgfbull.183.4.349

Giménez-Montsant J., Calvet F. \& Tucker M.E. 1999: Silica diagenesis in Eocene shallow-water platform carbonates, southern Pyrenees. Sedimentology46,969-984.https://doi.org/10.1046/j.1365-3091. 1999.00231.x

Goričan Š., Celarc B., Placer L. \& Košir A. 2013: Mesozoic stratigraphy and general structure of the Julian Alps (Eastern Southern Alps, NW Slovenia). In: Schuster R. (Ed.): $11^{\text {th }}$ Workshop on the Alpine Geological Studies \& $7^{\text {th }}$ European Symposium on Fossil Algae, Schladming. Berichte der Geol. Bundesanst. 99, 39-40.

Haas J. 2007: Paleogeographic setting and relationships of the Jurassic formations in the Bükk-Darnó area. Annals of the Hungarian Institution of Geology from 2006, 85-95.

Haas J. \& Kovács S. 2001: The Dinaridic-Alpine connection - as seen from Hungary. Acta Geologica Hungarica 44, 2-3, 345-363.

Haas J., Kovács S., Görög Á., Ozsvárt P., Matyók I. \& Pelikán P. 2006: Displaced Jurssic foreslope and basin deposits of Dinaridic origin in Northeast Hungary. Acta Geologica Hungarica 49, 2 , 125-163. https://doi.org/10.1556/ageol.49.2006.2.3

Haas J., Kovács S., Pelikán P., Kövér SZ., Görög Á., Ozsvárt P., Józsa S. \& Németh N. 2011: Remnants of the accretionary complex of the Neotethys Ocean in Northern Hungary. Földtani Közlöny 141, 2, 167-196 (in Hungarian with English abstract).

Haas J., Pelikán P., Görög Á. \& Józsa S. 2013: Stratigraphy, facies and geodynamic settings of Jurassic formations in the Bükk Mountains, North Hungary: its relations with the other areas of the Neotethyan realm. Geol. Mag. 150, 1, 18-49. https://doi. org/10.1017/S0016756812000246

Hansen E. 1971: Strain Facies. Springer-Verlag, Berlin, 1-207.

Harfi A.E., Guiraud M. \& Lang J. 2006: Deep-rooted "thick skinned" model for the High Atlas Mountains (Morocco). Implications for the structural inheritance of the southern Tethys passive margin. J. Struct. Geol. 28, 11, 1958-1976. https://doi.org/10.1016/j. jsg.2006.08.011

Héja G., Kövér Sz., Csillag G., Németh A. \& Fodor L. 2018: Evidence for pre-orogenic passive-margin extension in a Cretaceous fold-and-thrust belt on the basis of combined seismic and field data (western Transdanubian Range, Hungary). Int. J. Earth Sci. 107, 8, 2955-2973. https://doi.org/10.1007/s00531-018-1637-3

Jones O.T. 1939: The geology of the Clowyn Bay district: study of submarine slumping during the Salopian period. Quarterly Journal of Geological Society 95, 335-382.

Kázmér M. \& Kovács S. 1985: Permian-Paleogene paleogeography along the eastern part of the Insubric-Periadriatic lineament system: Evidence for continental escape of the Bakony-Drauzug unit. Acta Geologica Hungarica 28, 71-84.

Kovács S. 1982: Problems of the „Pannonian Median Massif” and the plate tectonic concept. Contributions based on the distribution of Late Paleozoic - Early Mesozoic isopic zones. Geol. Rundsch. 71, 2, 617-639.

Kovács S. 1984: North Hungarian Triassic facies types: a review. Acta Geologica Hungarica 27, 3-4, 251-264.

Kovács S. 1989: Geology of North Hungary: Paleozoic and Mesozoic terraines. In: Kecskeméti T. (Ed.): XXIst European Micropaleontological Colloquium. Guidebook, 15-36.
Kovács S., Haas J., Pelikán P., Józsa S., Ozsvárt P., Kiss G., Molnár F. \& Kövér Sz. 2010: Re-evaluation of the Mesozoic complexes of Darnó Hill (NE Hungary) and comparisons with Neotethyan accretionary complexes of the Dinarides and Hellenides - preliminary data. Central European Geology 53, 2-3, 205-231.

Kövér Sz., Fodor L., Kovács Z., Urs K.S., Haas J., Zajzon N. \& Szabo Cs. 2018: Late Triassic acidic volcanic clasts in different Neotethyan sedimentary mélanges: paleogeographic and geodynamic implications. Int. J. Earth Sci. 107, 8, 2975-2998. https:// doi.org/10.1007/s00531-018-1638-2

Less Gy. (Ed.), Gulácsi Z., Kovács P., Pentelényi L., Rezessy A. \& Sásdi L. 2002: Geological map of the Bükk Mountains (1:50 000). Geological Institute of Hungary, Budapest.

Lewis K.B. 1971: Slumping on a continental slope inclined at $1^{\circ}-4$. Sedimentology 16, 97-110.

Maffione M. \& van Hinsbergen J.J. 2018: Reconstruction plate boundaries in the Jurassic Neo-Tethys from the East and West Vardar Ophiolites (Greece and Serbia). Tectonics 37, 858-887. https://doi.org/10.1002/2017TC004790

Manatschal G. \& Nirrengarten M. 2015: The role of inheritance in forming and deforming hyper-extended rift systems and creating collisional orogens. Geotectonic Research 27, 1, 140-164.

Márton E. \& Fodor L. 1995: Combination of paleomagnetic and stress data - a case study from North Hungary. Tectonophysics 242, 99-114.

Márton E. \& Márton P. 1996: Large scale rotations in North Hungary during the Neogene as indicated by paleomagnetic data. Spec. Publ., Geol. Soc. London 105, 153-173.

Mohn G., Manatschal G., Beltrando M. \& Haupert I. 2014: The role of rift-inherited hyper-extension in Alpine-type orogens. Terra Nova 26, 347-353. https://doi.org/10.1111/ter.12104

Naylor M.A. 1981: Debris flow (olistostromes) and slumping on a distal passive continental margin: the Palombini limestoneshale sequence of the northern Apennines. Sedimentology 28, $837-852$.

Németh N. 2007: Structural features of the quarry at the Patkó Cliffs, Bükkzsérc and its surroundings. Földtani Közlöny 137, 4, 473-486 (in Hungarian with English abstract).

Ortner H. 2013: Deep water sedimentation on top of a growing wedge - interaction of thrusting, erosion and deposition in the Cretaceous Northern Calcareous Alps. Geo.Alp 13, 141-182.

Owen G. 1987: Deformation processes in unconsolidated sands. Spec. Publ., Geol. Soc. London 29, 11-24.

Owen G., Moretti M. \& Alfaro P. 2011: Recognising triggers for softsediment deformation: Current understanding and future directions. Sediment. Geol. 235, 133-140. https://doi.org/10.1016/ j.sedgeo.2010.12.010

Pamić J., Tomljenović B. \& Balen D. 2002: Geodynamic and petrogenic evolution of the Alpine ophiolites from the Central and NW Dinarides: an overview. Lithos 65, 113-142. https://doi.org/ 10.1016/S0024-4937(02)00162-7

Peel F.J. 2014: The engines of gravity-driven movement in passive margins: Quantifying therelative contribution of spreading vs. gravity sliding mechanisms. Tectonophysics 633, 126-142. https://doi.org/10.1016/j.tecto.2014.06.023

Pelikán P. 2012: Laskóvölgyi Formáció. In: Bércziné Makk A., Császár G., Főzy I., Grill J., Haas J., Ivancsics J., Kisházi P., Knauer J., Konda J., Nagy I., Pálfy J., Pentelényi L., Pelikán P., Raucsik B., Rálischné Felgenhauer E., Szabó Z., Szente I., Szinger B., Török Á. \& Vörös A. (Eds.): Lithostratic subdivision of Hungary - Jurassic. Magyarhoni Földtani Társulat, 124-126.

Pelikán P. \& Dosztály L. 2000: Jurassic formations of the Bükkzsérc boreholes (SW Bükk Mts, NE Hungary) and their structural setting. Földtani Közlöny 130, 1, 25-46 (in Hungarian with English abstract). 
Pelikán P. (Ed.), Budai T., Less GY., Kovács S., Pentelényi L. \& Sásdi L. 2005: Geology of the Bükk Mountains - Explanatory book to the Geological Map of the Bükk Mountains (1:50 000). Regional Map Series of Hungary, Geological Institute of Hungary, Budapest, 79-91.

Petrik A., Beke B., Fodor L. \& Lukács R. 2016: Cenozoic structural evolution of the southwestern Bükk Mts. and the southern part of the Darnó Deformation Belt (NE Hungary). Geol. Carpath. 67, 1, 83-104. https://doi.org/10.1515/geoca-2016-0005

Prestholm E. \& Walderhaug O. 2000: Synsedimentary Faulting in a Mesozoic Deltaic Sequence, Svalbard, Arctic Norway Fault Geometries, Faulting Mechanisms, and Sealing Properties. AAPG Bulletin 84, 4, 505-522. https://doi.org/10.1306/ C9EBCE37-1735-11D7-8645000102C1865D

Ramsey J.G. 1960: The deformation of early linear structures in areas of repeated folding. Journal of Geology 68, 1, 75-93.

Ramsey J.G. \& Hubert M.I. 1987: The Techniques of Modern Structural Geology. Academic Press, London.

Ribeiro C. \& Terrinha P. 2007: Formation, deformation and chertification of systematic clastic dykes in a differentially lithified carbonate multilayer. SW Iberia, Algarve Basin, Lower Jurassic. Sediment. Geol. 196, 201-215. https://doi.org/10.1016/j.sedgeo. 2006.06.001

Rožič B. \& Popit T. 2006: Resedimented Limestones in Middle and Upper Jurassic Succession of the Slovenian Basin. Geologija 49, $2,219-234$

Rožič B., Gerčar D., Oprčkal P., Švara A., Turnšek D., Kolar-Jurkovšek T., Udovč J., Kunst L., Fabjan T., Popit T. \& Gale L. 2018: Middle Jurassic limestone megabreccia from the southern margin of the Slovenian Basin. Swiss J. Geosci. 112, 163-180. https://doi.org/10.1007/s00015-018-0320-9

Schmid S.M., Bernoulli D., Fügenschuh B., Matenco L., Schefer S., Schuster R., Tischler M. \& Ustaszewski K. 2008: The AlpineCarpathian-Dinaridic orogenic system: correlation and evolution of tectonic units. Swiss J. Geosci. 101, 139-183. https://doi. org/10.1007/s00015-008-1247-3
Strachen L.J. \& Alsop G.I. 2006: Slump folds as estimators of paleoslope: a case study from the Fisherstreet Slump of Country Clare, Ireland. Basin Research 18, 451-470. https://doi.org/ 10.1111/j.1365-2117.2006.00302.x

Sudar M.N., Gawlick H-J., Lein R., Missoni S., Kovács S. \& Jovanović D. 2013: Depositional environment, age and facies of the Middle Triassic Bulog and Rid formations in the Inner Dinarides (Zlatibor Mountain, SW Serbia): evidence for the Anisian breakup of the Neotethys Ocean. Neues Jahrb. Geol. Palaontol. Abh. 269, 3, 291-320. https://doi.org/10.1127/0077-7749/2013/ 0352

Szoldán Zs. 1990: Middle Triassic magmatic sequences from different tectonic settings in the Bükk Mts. NE Hungary. Acta Mineralogica Petrologica Szegedenesis 31, 25-42.

Tanner P.W.G. 1998: Interstratal dewatering origin for polygonal patterns of sand-filled cracks: a case study from late Proterozoic metasediments of Islay, Scotland. Sedimentology 45, 71-89.

Tőkés L. \& Sztanó O. 2015: Tricks of turbidity currents and confined turbidite basins: a review. Földtani Közlöny 145, 2, 151-172 (in Hungarian with English abstract).

Tollmann A. 1987: Neue Wege in der Ostalpengeologie und die Beziehungenzum Ostmediterran. Mitteilungen der Österreichischen Geologischen Gesellschaft 80, 47-113.

Velledits F. 2000: Evolution of the area from the Berva Valley to the Hór Valley in the Middle - Upper Triassic. Földtani Közlöny 130, 1, 47-93 (in Hungarian with English abstract).

Velledits F. 2006: Evolution of the Bükk Mountains (NE Hungary) during the Middle-Late Triassic asymmetric rifting of the Vardar-Meliata branch of the Neotethys ocean. Int. J. Earth Sci. 95, 395-412. https://doi.org/10.1007/s00531-005-0041-y

Weinberger R., Levi T., Marco S. \& Alsop G.I. 2017: Kinematics of Mass Transport Deposits Revealed by Magnetic Fabrics. Geophys. Res. Lett. 44, 15, 7743-7749. https://doi.org/10.1002/ 2017GL074471

Woodcock N.H. 1979: The use of slump structures as paleoslope orientation estimators. Sedimentology 26, 83-99.

\section{Appendix}

Sample localities

\begin{tabular}{|c|c|c|c|}
\hline Locality & Latitude* & Longitude* & Number of data \\
\hline Bzs01 & $47^{\circ} 58.125^{\prime} \mathrm{N}$ & $20^{\circ} 29.180^{\prime} \mathrm{E}$ & 25 \\
\hline Bzs02 & $47^{\circ} 58.132{ }^{\prime} \mathrm{N}$ & $20^{\circ} 29.155^{\prime} \mathrm{E}$ & 54 \\
\hline Bzs03 & $47^{\circ} 58.124^{\prime} \mathrm{N}$ & $20^{\circ} 29.186^{\prime} \mathrm{E}$ & 15 \\
\hline Bzs04 & $47^{\circ} 58.129^{\prime} \mathrm{N}$ & $20^{\circ} 29.190^{\prime} \mathrm{E}$ & 11 \\
\hline Bzs05 & $47^{\circ} 58.129^{\prime} \mathrm{N}$ & $20^{\circ} 29.161^{\prime} \mathrm{E}$ & 41 \\
\hline Bzs06 & $47^{\circ} 58.127^{\prime} \mathrm{N}$ & $20^{\circ} 29.145^{\prime} \mathrm{E}$ & 42 \\
\hline Bzs07 & $47^{\circ} 58.120^{\prime} \mathrm{N}$ & $20^{\circ} 29.143^{\prime} \mathrm{E}$ & 20 \\
\hline Bzs08 & $47^{\circ} 58.130^{\prime} \mathrm{N}$ & $20^{\circ} 29.169^{\prime} \mathrm{E}$ & 32 \\
\hline Bzs09 & $47^{\circ} 58.129^{\prime} \mathrm{N}$ & $20^{\circ} 29.184^{\prime} \mathrm{E}$ & 15 \\
\hline Bzs10 & $47^{\circ} 58.129^{\prime} \mathrm{N}$ & $20^{\circ} 29.150^{\prime} \mathrm{E}$ & 4 \\
\hline Bzs11 & $47^{\circ} 58.131^{\prime} \mathrm{N}$ & $20^{\circ} 29.134^{\prime} \mathrm{E}$ & 4 \\
\hline Bzs49 & $47^{\circ} 58.125^{\prime} \mathrm{N}$ & $20^{\circ} 30.234^{\prime} \mathrm{E}$ & 4 \\
\hline Bzs53 & $47^{\circ} 58.260^{\prime} \mathrm{N}$ & $20^{\circ} 30.218^{\prime} \mathrm{E}$ & 7 \\
\hline Bzs62 & $47^{\circ} 59.543^{\prime} \mathrm{N}$ & $20^{\circ} 30.375^{\prime} \mathrm{E}$ & 11 \\
\hline Bzs70 & $47^{\circ} 59.004^{\prime} \mathrm{N}$ & $20^{\circ} 29.230^{\prime} \mathrm{E}$ & 33 \\
\hline Pt01 & $47^{\circ} 58.215^{\prime} \mathrm{N}$ & $20^{\circ} 29.299^{\prime} \mathrm{E}$ & 14 \\
\hline Pt02 & $47^{\circ} 58.217^{\prime} \mathrm{N}$ & $20^{\circ} 29.306^{\prime} \mathrm{E}$ & 6 \\
\hline Pt03 & $47^{\circ} 58.219^{\prime} \mathrm{N}$ & $20^{\circ} 29.329^{\prime} \mathrm{E}$ & 27 \\
\hline
\end{tabular}

*GPS coordinates are referenced in geographical coordinate system WGS84. 